\title{
The Relationship Between Board Composition and the Ratings Given to Green Bonds: An Empirical Analysis
}

\author{
Andrea Lippi ${ }^{1}$ \\ ${ }^{1}$ Università Cattolica del Sacro Cuore sede di Piacenza e Cremona, Piacenza, Italy \\ Correspondence: Andrea Lippi, Università Cattolica del Sacro Cuore sede di Piacenza e Cremona, Piacenza, Italy. \\ E-mail: andrea.lippi@unicatt.it
}

Received: February 14, 2021

Accepted: March 24, 2021 Online Published: March 28, 2021

doi:10.5539/jms.v11n1p126

URL: https://doi.org/10.5539/jms.v11n1p126

\begin{abstract}
Due to the growing number of green bond issues, a lack of mandatory standards and thus the growing phenomenon of greenwashing, an increasingly greater role is assumed by external auditors who are called upon to certify the 'greenness' of green bonds. These include rating agencies, which may be called on to express a green rating for each issue of green bonds. Based on a unique dataset made up of 66 green bond issues together with their respective green ratings from 2015 to 2020, the aim of this paper is to test the relationship between issuers' board compositions and the green rating assigned to each bond issue. The results obtained confirm some conclusions already present in the existing literature and also open a new field of research concerning the green bond market, which has so far been little analysed, especially with reference to corporate governance.
\end{abstract}

Keywords: green bond, green bond rating, board composition, board diversity

\section{Introduction}

In recent years, of the social and responsible investments (SRI) available on the market, green bonds have gained increasing interest from investors. A green bond is issued with the aim of supporting projects that have a positive impact on the environment, such as the development of clean energy, the sustainable use of land, and energy efficiency. The Climate Bond Initiative (CBI) reports that in 2019 the green bond market included issues to a value exceeding USD 250 billion. The greatest growth occurred in Europe, with an increase of USD 50 billion compared to $2018(+74 \%)$, representing 57\% of global expansion. Within the private sector, in recent years financial corporations have had the highest market share of issues; however, non-financial corporations reached the same level in 2019. In the same year, building, energy and transport were the three largest categories as regards green bond issues.

The attractiveness of green bonds to investors, which is generated by a growing concern as regards environmental issues, may be a temptation for many companies to issue bonds with a green label but without a real intention to allocate the money raised to environmental projects (the so-called 'greenwashing' phenomenon). In order to distinguish real green bonds from those which are greenwashed, in June 2018 the International Capital Market Association (ICMA) issued the Green Bond Principles (GBP), specific guidelines for identifying a green bond. They can be summarized in the following four points: i) the bond issuer must clearly and unequivocally identify the destination of bond revenues; ii) the bond destination projects must be included on a specific list of categories and must be selected through a rigid and objective process; iii) the issuer must ensure maximum transparency in communicating the management of the bond flows; iv) reports must be published to keep investors updated on the progress of the financed projects.

However, GBP are not mandatory; issuers may or may not follow them. For this reason, the ICMA has introduced a check on the true nature of green bonds to be carried out by an external auditor who must possess the characteristics of independence, professionalism, integrity, diligence and confidentiality. The auditor's task is to draw up a report for each green bond issue, analysing the issuance procedures and the underlying project/s. More specifically, the issuers can obtain a merit judgment on an individual green bond issue by choosing between: a) second party opinion: a certification on compliance with the GBP prepared by institutions with high expertise in the environmental sector and which are independent from the issuer; $b$ ) verification: the issuer can request an independent verification of the traceability of the green bond revenues, on the soundness of the financed environmental project and the suitability of the reporting; c) certification: issued by qualified third 
parties and experts, it must evaluate the green bond and the use of proceeds in compliance with the GBP; d) green rating: rating agencies issue a specific green rating for each green bond issue. It is important to underline that the green rating is different from the issuer rating: the green rating is based on the evaluation of environmental performance of the green bond and the project underlying the issue itself. It should not to be confused with the issuer's rating, which is based on specific characteristics of the issuer. The 2019 CBI report highlights that about $60 \%$ of green bonds issued had a second party opinion certification, while the green rating option covered about $3 \%$ of the issues (equal to USD 8 billion of issuance). The rating agencies that issued the highest number of green ratings included Moody's, Standard \& Poor's, CCX, China Bond Rating, R\&J, JCR and RAM. At the international level, from 2015 to the end of June 2020 there were 79 green bond issues with green ratings.

For each of these 79 issues, during the investigation described in this paper the issuer was identified and socio-demographic information for each member of the board collected. Considering the lack of information available for some issuers, a unique dataset made up of 66 issues $(83.54 \%$ of the total) was created. The purpose of this research is to verify whether there is a relationship between the board composition of the issuer and the green bond rating, based on this unique dataset. The working hypothesis is that the board of directors is a group of people and their decisions are made by the majority of them. The issuing of green bonds depends upon several factors and, among them, the directors' interest in the environment may influence their choice regarding these issues. This research attempts to establish whether there is a relationship between board composition and (green) bond issues. If such a relationship exists, it could be exploited in the opposite direction by investors in their assessment of bond issues. To my knowledge, this is the first paper to analyse the relationship between companies' board composition and the rating attributed to green bond issues.

The results obtained are important from a theoretical and academic perspective because they confirm existing literature on board composition and board diversity, adding an original analysis concerning the recent phenomenon of green bonds. Furthermore, from the investors' point of view, our results may allow identification of the best green bonds through consideration of board composition. In other words, a ranking of the quality of green bond issues could be achieved by analysing the issuer's board composition. In addition, this research should stimulate debate between researchers and regulators as to the desirability of establishing a green certification for boards of directors.

The remainder of this paper is organized as follows. Section 2 presents the main literature on board composition and board diversity and introduces the research hypotheses. Section 3 introduces the sample used in the analysis and Section 4 shows the obtained results. Section 5 discusses the obtained results and concludes.

\section{Literature Review and Development of Hypotheses}

The variables most widely used in the literature to describe the impact of corporate governance on ESG topics are related to board size, the presence of women on the board, the proportion of independent directors, the age of board members, their level of education, and nationality (e.g., Post et al., 2011; Rao \& Tilt, 2016; Setò-Pamies, 2015). In the sub-sections below, I develop my hypotheses for each of these characteristics.

\subsection{Board Size}

Krishnan and Visvanathan (2009) and Pathan (2009) argue that board size depends on a firm's complexity, so its sector and size are important factors influencing the number of directors. Baker and Gompers (2003), Kocher and Sutter (2005) and Coles et al. (2008) demonstrate that firms with complex businesses need larger boards because of the difficulties involved in monitoring and advising such corporations.

Allegrini and Greco (2013) find a positive and significant effect of board size on governance disclosure in Italy. Esa and Ghazali (2012) demonstrate a positive effect of board size on the extent of CSR disclosure in Malaysia. However, Giannarakis (2014) does not report a significant impact of board size on ESG disclosure.

Laksmana (2008) and Guest (2009) argue that smaller boards might have a low degree of diversification in terms of education, expertise, gender and stakeholder representation. According to De Andres et al. (2005) and Ahmed et al. (2006), smaller boards are expected to be more effective in monitoring and controlling firm governance than larger boards. In particular, Ahmed et al. (2006) and Dey (2008) find that the commitment of directors is higher on smaller boards.

In the light of the above evidence, I advance the following hypothesis:

Hypothesis 1. The larger the board of directors, the lower the green bond rating. 


\subsection{Board Age}

Age diversity within the $\mathrm{BoD}$ is expressed as the coexistence of different generations, and therefore of values, motivational goals and experiences influencing the decision-making processes adopted by directors. According to Botwinick (1977) and Burke and Light (1981), cognitive abilities including learning ability, memory and reasoning decrease as people age. Moreover, Carlson and Karlsson (1970) and Vroom and Pahl (1971) demonstrate that older executives tend to avoid risky decisions.

However, it has been shown that the relationship between age and risk-propensity is not clear. Campbell (1987) highlights the fact that younger managers seem to handle new and creative ideas better than older managers; according to Guthrie and Olian (1991), they tend to implement more risky and innovative growth strategies. According to Morin and Suarez (1983), Brown (1990), Bakshi and Chen (1994) and Palsson (1996) a positive correlation between age and risk-propensity is identifible. Riley and Chow (1992), Halek and Eisenhauer (2001) and Harrison et al. (2007) show that risk aversion decreases with age up until 65 years of age and then increases significantly. Cohen and Einay (2007) find a U-shape in the relationship between age and risk-seeking. Thus senior advisors are more experienced and represent a form of accumulated skill-based competencies, while younger directors seem to be more dynamic, smarter, open to technological change, and active in driving business success and future planning (Handajani et al., 2014).

However, age is negatively associated with environmental attitudes and knowledge of environmental issues (Diamantopoulos et al., 2003). Hafsi and Turgut (2013) argue that a board's average age has no effect on the extent of CSR disclosure, while according to Ferrero-Ferrero et al. (2015) a board of mixed age composition improves the integration of ESG issues into management processes.

Therefore, I propose the following hypothesis:

\section{Hypothesis 2. The younger the board, the higher the green bond rating.}

\subsection{Board Independence}

Several studies document a positive relationship between board independence and CSR (Chen \& Jaggi, 2000; Amhed et al., 2006; Jo \& Harjoto, 2011; Post et al., 2011; Jizi et al., 2014; Ong \& Djajadikerta, 2018). Kaymak and Bektas (2017) indicate that board independence and board size are strongly and positively related to several CSR practices. Ibrahim and Angelidis (1995) and Ibrahim et al. (2003) find that independent directors are more concerned about charitable and philanthropic themes associated with CSR, than inside directors. Webb (2004) finds that firms that engage in CSR initiatives tend to have more independent directors.

Haniffa and Cooke (2005), Lim et al. (2007), Prado-Lorenzo and Garcia-Sanchez (2010), Nurhayati et al. (2015) and Naciti (2019) find that the presence of independent directors on boards has a negative impact on social and environmental disclosure while Mallin et al. (2013) find the same relationship with reference to environmental performance. Further studies document a non-significant association (Walls \& Hoffman, 2013; Rao \& Tilt, 2016; Walls \& Berrone, 2017).

According to Haniffa and Cooke (2005) and Jo and Harjoto (2011) a greater proportion of independent directors increases focus on social and environmental issues, while Holtz and Sarlo Neto (2014) find a positive relationship between board independence and ESG disclosures. Cucari et al. (2018) and Gallego-Alvarez and Pucheta-Martínez (2020) document a significant positive association between companies' board independence and CSR involvement. Further, Hussain et al. (2018), Ibrahim and Hanefah (2016) and Cullinan et al. (2019) find that independent directors are associated with higher levels of CSR performance.

In consideration of the above evidence, I advance the following hypothesis:

Hypothesis 3. There is a positive relationship between the number of independent directors on the board and the green bond rating.

\subsection{Board Gender Diversity}

Regarding the relationship between board diversity and CSR outcomes, Post et al. (2011) and Ferrero-Ferrero et al. (2015) find that women directors encourage companies to adopt a more socially responsible approach. Generally, the literature suggests that firms with more women on their boards tend to act in more socially responsible ways than those with no women or fewer women. Bear et al. (2010), Setó-Pamies (2015), Ibrahim and Hanefah (2016) and Matuszak et al. (2019) find that the presence of females on the board is significantly and positively associated with CSR disclosure.

Further, female directors on boards may enhance companies' awareness of environmental and social issues and promote the adoption of proactive strategies to respond to corporate stakeholders' social and ethical demands and 
expectations (Al-Shaer \& Zaman, 2016; Ben-Amar et al., 2017; Hollindale et al., 2019). Boulouta (2013), Hussain et al. (2018) and Cullinan et al. (2019) argue that female directors enhance the sustainability performance of a company. Moreover, several studies suggest that firms with a higher percentage of females on the board present a higher level of charitable giving (Wang \& Coffey, 1992; Williams, 2003), more favorable work environments (Bernardi et al., 2006), higher levels of environmental CSR (Post et al., 2011) and more apprehension concerning climate change (Ciocirlan \& Pettersson, 2012). However, some studies (e.g., Konrad et al., 2008; Fernandez-Feijoo et al., 2012, 2014; Manita et al., 2018) point out that to have a significant and positive impact on sustainability and corporate governance, there must be at least three women on a BoD. Specifically, Post et al. (2011) argue that boards of directors with three or more female members have a high regard for environmental issues.

There are also studies with different, contradictory results. According to Kilic et al. (2015) and Glass et al. (2016) there is a weak, statistically significant positive impact of board gender diversity on social and environmental reporting, while Deshenes et al. (2015) and Prado-Lorenzo et al. (2009) find a negative association between social and environmental practices and the presence of females on a board. Other studies (Khan, 2010; Walls et al., 2012; Galbreath, 2013; Mallin et al., 2013; Amran et al., 2014; Giannarakis, 2014; Alazzani et al., 2017) find no significant relationship between board gender diversity and a firm's social and environmental policies.

Based on this literature, the following hypothesis is proposed:

Hypothesis 4. The presence of women on the board positively affects the green bond rating.

\subsection{Educational Level}

Many studies (e.g., Datta \& Rajagopalan, 1998; Hambrick \& Mason, 1984; Wailderdsak \& Suehiro, 2004) consider educational level a good proxy for human capital, knowledge, or intellectual competence. In the literature the subject studied is also considered. Christy et al. (2010) show that the proportion of board members holding a financial degree is negatively associated with the market risk of equity in Australia. Litov et al. (2014) find that lawyer directors reduce corporate risk-taking and increase firm value. Audretsch and Lehmann (2006) argue that directors with academic backgrounds can enhance the competitive advantage of firms by facilitating access to and the absorption of external knowledge spillover.

Therefore, I propose the following hypothesis:

Hypothesis 5. The higher the proportion of economic and financial degrees held by the members of the board, the higher the green bond rating.

\subsection{Board Nationality}

The debate on board diversity in terms of nationality contrasts a heterogeneous board with its homogeneous counterpart (Hambrick et al., 1996). Rao and Tilt (2016) argue that national diversity in heterogeneous boards improves the quality of decision making for social and environmental actions that promote higher sustainability performance. Harjoto et al. (2019) find that board diversity in terms of nationality is positively associated with corporate social performance and Naciti (2019) demonstrates a positive relationship between board nationality diversity and firm sustainability performance. However, Anazonwu et al. (2018) using a sample of listed manufacturing firms in Nigeria, find no significant positive influence of board nationality diversity on firm sustainability reports, and Janggu et al. (2014), considering 100 publicly listed companies in Malaysia, find that foreign directors do not have a significant influence on sustainability disclosure.

Thus, the literature on the relationship between board nationality diversity and the ESG issue is controversial and heterogeneous. In formulating my hypothesis, I therefore consider the board of directors as a group of people who have to make a specific decision about the issuing of green bonds. From this perspective, according to Gibson (2004), members of a group from different cultures are more likely to respond differently to the same event or managerial decision-making situation. Moreover, Souren et al. (2004) argue that diversity in ethnic origin and nationality appears to interfere with group processes more than does homogeneity in organizational teams. On the contrary, Zhang et al. (2007) argue that homogeneous teams share common views and are likely to interpret and evaluate situational events and management practice in similar ways, i.e., they generally report stronger affinity than heterogeneous teams.

Based on the above considerations, the following hypothesis is proposed:

Hypothesis 6. The higher the number of directors of the same nationality on a board, the higher the green bond rating. 


\section{Data and Methodology}

From 2015 to the end of June 2020, at the international level there were 79 green bond issues accompanied by a green rating. For each of them, the following information was collected: the green rating attributed to the single issue, the name of the green bond issuer and the board composition of each issuer. For each board member, principal socio-demographic information was gathered. Table 1 lists and describes the variables used in this study and shows the expected sign of their impact on the green bond rating. Unfortunately, for some issuers it was not possible to collect all the information of interest: these issuers were excluded from the sample. As a result, the sample consists of 66 green bond issues, representing $83.54 \%$ of the total.

Table 1. Description of variables

\begin{tabular}{|c|c|c|}
\hline \multicolumn{3}{|c|}{$\begin{array}{l}\text { Variable Description } \\
\text { Dependent variable: }\end{array}$} \\
\hline $\begin{array}{l}\text { Dependent va } \\
\text { greenrating }\end{array}$ & $\begin{array}{l}\text { The rating assigned by an agency to each green bond issue in the sample. It ranges from } 0 \text { (worst level) } \\
\text { to } 3 \text { (best level). }\end{array}$ & \\
\hline $\begin{array}{l}\text { Independent } 1 \\
\text { sector }\end{array}$ & $\begin{array}{l}\text { Dummy variable: equal to } 1 \text { if the firm belongs to the banking, financial and insurance sector; } 0 \\
\text { otherwise }\end{array}$ & \\
\hline Ndirectors & Number of directors on the board for each company & - \\
\hline age & The average age of the directors on the board for each company & - \\
\hline independent & The percentage of independent directors on the board for each company & + \\
\hline women & The share of women on the board for each company & + \\
\hline degree & The percentage of graduate directors on the board for each company & + \\
\hline findegree & The percentage of graduates in Economics and Finance on the board for each company & + \\
\hline nationality & $\begin{array}{l}\text { Dummy variable: } 1 \text { if the percentage of directors of the same nationality on the board for each } \\
\text { companyis at least } 75 \% ; 0 \text { otherwise }\end{array}$ & + \\
\hline tenor & The length of loans in years & \\
\hline amount & The logarithm of the amount of each issue (in USD) & \\
\hline currency & $\begin{array}{l}\text { Dummy variable: } 0 \text { if the issue currency is USD; } 1 \text { if the issue currency is EUR; } 2 \text { if the issue currency } \\
\text { is JPY; } 3 \text { otherwise }\end{array}$ & \\
\hline
\end{tabular}

In Table 1 the 'tenor' measures the time in years from origination to maturity date. It is used as a control variable as suggested in the studies by Bauer and Hann (2010), Cooper and Uzun (2015) and Eichhholtz et al. (2019). 'Amount' indicates the bond issue amount used as a control variable in the studies by Bauer and Hann (2010), Cooper and Uzun (2015), Eichhholtz et al. (2019) and Oikonomou et al. (2014). Given the different currencies used for the issues, 'currency' was also used as a control variable. Table 2 summarizes the descriptive statistics of the variables used in the analysis while Table 3 shows the correlation matrix.

Table 2. Descriptive statistics

\begin{tabular}{lllll}
\hline Variable & Mean & Std. Dev. & Min & Max \\
\hline greenrating & 2.7273 & 0.6690 & 0 & 3 \\
sector & 0.4091 & 0.4954 & 0 & 1 \\
Ndirectors & 7.8333 & 4.9071 & 1 & 18 \\
age & 58.2762 & 7.4835 & 35 & 72 \\
independent & 0.1215 & 0.1903 & 0 & 0.67 \\
women & 0.1103 & 0.1358 & 0 & 0.67 \\
degree & 0.9670 & 0.0624 & 0.75 & 1 \\
findegree & 0.5076 & 0.2637 & 0 & 1 \\
nationality & 0.9242 & 0.2667 & 0 & 1 \\
tenor & 9.2121 & 7.4349 & 2 & 40 \\
amount & 21.1191 & 1.9117 & 14.40 & 23.63 \\
currency & 1.7121 & 0.9243 & 0 & 3 \\
\hline
\end{tabular}

Table 2 shows the green bond rating is on average very high, 2.7 out of a maximum value of 3 . The average number of directors is 7.8 while the average age is around 58 years old. The average number of independent and women directors is not particularly high: $12.15 \%$ and $11.03 \%$ respectively. More in detail, 43 companies have 
no independent directors while 30 have no women on their boards. The level of education is on average very high: $96.70 \%$ of directors are graduates. Moreover, $50 \%$ of directors have a degree in economics and finance. About $10.6 \%$ of the issuers have a board made up of at least $75 \%$ directors of the same nationality. The average tenor of the issued bonds is 9 years with a very high variability $(\mathrm{SD}=7.43)$.

Table 3. Correlation matrix

\begin{tabular}{|c|c|c|c|c|c|c|c|c|c|c|c|c|}
\hline & 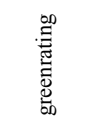 & 志 & 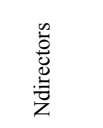 & $\underset{\varpi}{\stackrel{g}{\circ}}$ & 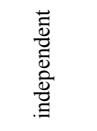 & 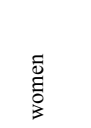 & $\begin{array}{l}\stackrel{\Xi}{0} \\
\stackrel{5}{0} \\
\stackrel{0}{0}\end{array}$ & 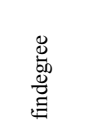 & 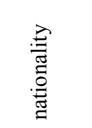 & 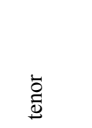 & $\begin{array}{l}\text { 咅 } \\
\text { 罜 }\end{array}$ & 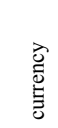 \\
\hline greenrating & 1 & & & & & & & & & & & \\
\hline sector & 0.0633 & 1 & & & & & & & & & & \\
\hline Ndirectors & -0.1265 & -0.1487 & 1 & & & & & & & & & \\
\hline age & -0.2341 & 0.0206 & 0.1356 & 1 & & & & & & & & \\
\hline independent & -0.1616 & -0.0556 & 0.2165 & -0.0823 & 1 & & & & & & & \\
\hline women & -0.3022 & -0.2054 & 0.2742 & -0.1520 & 0.2494 & 1 & & & & & & \\
\hline degree & -0.0643 & 0.0507 & 0.0315 & 0.0285 & -0.1053 & -0.0202 & 1 & & & & & \\
\hline findegree & -0.1712 & 0.1290 & 0.0988 & -0.4163 & 0.1586 & 0.0033 & -0.0247 & 1 & & & & \\
\hline nationality & -0.0314 & 0.2382 & -0.1862 & -0.0397 & -0.0371 & -0.1523 & -0.1527 & -0.1077 & 1 & & & \\
\hline tenor & -0.0872 & -0.2703 & $-0-0332$ & -0.0173 & -0.0723 & -0.0212 & -0.1438 & -0.1513 & 0.0548 & 1 & & \\
\hline amount & 0.2632 & 0.1920 & 0.0864 & 0.2545 & -0.1357 & -0.4128 & 0.1114 & -0.1575 & 0.0766 & 0.0752 & 1 & \\
\hline currency & -0.0045 & 0.2275 & -0.0616 & 0.0540 & 0.1311 & -0.2028 & 0.1900 & 0.0470 & 0.2223 & -0.2238 & 0.4628 & 1 \\
\hline
\end{tabular}

In order to test our research hypotheses, the following ordered logit regressions were run:

$$
\begin{aligned}
& \text { greenrating }=\beta_{1} \text { sector }+\beta_{2} \text { Ndirectors }+\beta_{3} \text { age }+\beta_{4} \text { independent }+\beta_{5} \text { women }+\beta_{6} \text { degree }+ \\
& \beta_{7} \text { findegree }+\beta_{8} \text { nationality }+\beta_{9} \text { tenor }+\beta_{10} \text { amount }+\beta_{11} \text { currency }+\varepsilon \\
& \text { greenrating }=\beta_{1} \text { sector }+\beta_{2} \text { Ndirectors }+\beta_{3} \text { age }+\beta_{4} \text { independent }+\beta_{5} \text { women }+\beta_{6} \text { findegree }+ \\
& \beta_{7} \text { nationality }+\beta_{8} \text { tenor }+\beta_{9} \text { amount }+\beta_{10} \text { currency }+\varepsilon
\end{aligned}
$$

The ordered logit model is justified bearing in mind that the bond rating presents a specific increasing order from the lower to the higher. In (1) the percentage of degree-holdingdirectors and the share of directors with an economic and financial degree were considered; in (2) the percentage of directors with an economic and financial degree only.

\section{Results}

Table 4 presents the results of the analysis; the estimates reported in column (1) consider equation (1) while the results in column (2) are related to equation (2).

Table 4. The determinants of the green bond rating

\begin{tabular}{lll}
\hline VARIABLES & $\mathbf{( 1 )}$ & $\mathbf{( 2 )}$ \\
\hline sector & 0.796 & 0.693 \\
& $(1.027)$ & $(0.823)$ \\
Ndirectors & $-0.204^{*}$ & $-0.204^{*}$ \\
& $(0.123)$ & $(0.122)$ \\
age & 0.0736 & 0.0706 \\
& $(0.0550)$ & $(0.0573)$ \\
independent & $6.364^{* * *}$ & $6.286^{* * *}$ \\
& $(2.436)$ & $(2.407)$ \\
women & -3.759 & -4.214 \\
& $(3.949)$ & $(3.668)$ \\
\hline
\end{tabular}




\begin{tabular}{lll}
\hline degree & -2.443 & - \\
& $(6.212)$ & - \\
findegree & $-4.059^{* *}$ & $-3.948^{* *}$ \\
& $(1.905)$ & $(1.685)$ \\
nationality & -0.0109 & 0.112 \\
& $(1.880)$ & $(1.799)$ \\
tenor & $-0.128^{* *}$ & $-0.126^{*}$ \\
& $(0.0647)$ & $(0.0652)$ \\
amount & $0.765^{* * *}$ & $0.740^{* * *}$ \\
& $(0.283)$ & $(0.281)$ \\
currency & $-1.150^{*}$ & $-1.173^{* *}$ \\
& $(0.609)$ & $(0.594)$ \\
\hline Observations & 66 & 66 \\
Pseudo R2 & 0.2992 & 0.2973 \\
\hline
\end{tabular}

Note. Ordered logit regression. The dependent variable is greenrating. The table reports the odds ratio; ${ }^{* * *} \mathrm{p}<0.01,{ }^{* *} \mathrm{p}<0.05,{ }^{*} \mathrm{p}<0.1$. Robust standard errors in parentheses.

Overall, the results reported in columns (1) and (2) in Table 4 converge, allowing a single comment on both.The first significant result that emerges is that the number of directors on the board has a negative impact on the green bond rating. This result corroborates the existing literature in favour of smaller boards and thus $\mathrm{H} 1$ is confirmed. $\mathrm{H} 2$ is not confirmed, as the average age of directors has no significant impact on the attribution of the green rating. Table 4 shows a very strong positive and significant relationship between the percentage of independent directors and the level of rating expressed for the bond issues, so $\mathrm{H} 3$ is confirmed. On the contrary, $\mathrm{H} 4$ is rejected,given that the percentage of women on the board has no significant impact on the green bond rating. This can be justified by the low number of women on the boards of the issuers examined. The percentage of graduates on the board does not have a significant impact on the green bond rating, while the percentage of directors with a degree in economics and finance has a significant influence on the green rating. However, this impact is negative,so H5 is rejected. H6 is rejected as well because directors being of the same nationality has no impact on the green rating. The results obtained from the control variables included in the model are also interesting. In fact, the longer the bond tenor, the lower the rating attributed to the green bond. Viceversa, the higher the value of the issue, the better the rating level obtained by the green bond. Finally, the lowest ratings are assigned to dollar issues.

\section{Discussion and Conclusions}

The results obtainedfrom the analysis confirm and corroborate some conclusions found in the existing literature, opening a new field of research linked to green bond issues and the related quality certifications. In particular, in the literature board size gives rise to two opposing strands: on the one hand, many studies demonstrate the importance of larger boards, while others advocate the efficiency and effectiveness of smaller boards. With reference to the rating level obtained bygreen bond issues, the results presented in this paper favour smaller boards.

In the literature, the role of independent directors on the board does not lead to converging conclusions. The present analysis supports their positive role in obtaining a better rating for green bond issues.

Contrary to our expectations, directors holding an economic and financial degree have a negative impact on the level of the green bond rating. This unexpected result may be due to a combination of determinants: firstly, the average age of board members, which is quite high. This supports the idea that the degree courses of these directors did not consider environmental issues, in contrast with current study programs in many economics faculties. Secondly, and as a consequence, these directors are more oriented towards obtaining short-term performance, while green investments take much longer to produce their effects.

Particular attention should be paid to the meaning of the control variables included in the analysis. The negative relationship between bond tenor and the bond rating can be explained by the fact that long term uncertainty about the macroeconomic scenario is higher than over a shorter period. Therefore, the issuer's financial solvency could be compromised over the longer term, with negative effects on bonds' security. Furthermore, the larger the bond issue size, the greater the possibility of its market remaining liquid. For this reason, the results obtained showed a positive relationship between the total amount of the issues and the bond rating. Finally, the negative relationship between the bond rating and dollar issues may be due to the fact that the majority of the bonds 
included in the analysis were issued in Euros while dollar issues are still quite modest. In conclusion, the results obtained suggest some characteristics that green bond issues should have in order to obtain a high level of rating: being a large issue, not having a long tenor and not being in US dollars.

The green bond market offers many avenues for future research. It is still an area which has received little in-depth attention,and which presents multiple facets to be analysed, including that addressed in this paper. Constructive debate and discussion between academics and supervisory authorities would be useful, in order to evaluate the need to define standards so as to permit certification of the green propensity of the boards of individual companies. This could greatly help investors, especially those in the retail sector, who are interested in allocating their investments to companies that are attentive to environmental issues. Indeed, the topic of SRI attracts much attention from investors, who are faced with a plethora of investment opportunities. However, very often they are not able to determine the truthfulness and quality of the proposed investment. Thus external certification, recognized by the supervisory authorities on the basis of compliance with predefined standards,including at the level of the composition of boards of directors, could be useful for dispelling some of the doubts interfering with investors' decision-making processes.

\section{References}

Ahmed, K., Hossain, M., \& Adams, M. B. (2006). The effects of board composition and board size on the informativeness of annual accounting earnings. Corporate Governance: An International Review, 14(5), 418-431. https://doi.org/10.1111/j.1467-8683.2006.00515.x

Al-Shaer, H., \& Zaman, M. (2016). Board gender diversity and sustainability reporting quality. Journal of Contemporary Accounting \& Economics, 12(3), 210-222. https://doi.org/10.1016/j.jcae.2016.09.001

Alazzani, A., Hassanein, A., \& Al-Janadi, Y. (2017). Impact of gender diversity on social and environmental performance evidence from Malaysia. Corporate Governance, 17(2), 266-283. https://doi.org/10.1108/CG-12-2015-0161

Allegrini, M., \& Greco, G. (2013). Corporate boards, audit committees and voluntary disclosure: Evidence from Italian listed companies. Journal of Management \& Governance, 17(1), 187-216. https://doi.org/10.1007/s10997-011-9168-3

Amran, A., Lee, S. P., \& Devi, S. S. (2014). The influence of governance structure and strategic corporate social responsibility toward sustainability reporting quality. Business Strategy and the Environment, 23(4), 217-235. https://doi.org/10.1002/bse.1767

Anazonwu, H. O., Egbunike, F. C., \& Gunardi, A. (2018). Corporate Board Diversity and Sustainability Reporting: A Study of Selected Listed Manufacturing Firms in Nigeria. Indonesian Journal of Sustainability Accounting and Management, 2(1), 65-78. https://doi.org/10.28992/ijsam.v2i1.52

Audretsch, D. B., \& Lehmann, E. (2006). Entrepreneurial access and absorption of knowledge spillovers: Strategic board and managerial composition for competitive advantage. Journal of Small Business Management, 44(2), 155-166. https://doi.org/10.1111/j.1540-627X.2006.00161.x

Baker, M., \& Gompers, P. A. (2003). The determinants of board structure at the initial public offering. The Journal of Law and Economics, 46(2), 569-598. https://doi.org/10.1086/380409

Bakshi, G. S., \& Chen, Z. (1994). Baby boom, population aging, and capital markets. Journal of Business, 165-202. https://doi.org/10.1086/296629

Bauer, R., \& Hann, D. (2010). Corporate Environmental Management and Credit Risk. SSRN Electronic Journal. https://doi.org/10.2139/ssrn.1660470

Bear, S., Rahman, N., \& Post, C. (2010). The impact of board diversity and gender composition on corporate social responsibility and firm reputation. Journal of Business Ethics, 97(2), 207-221. https://doi.org/10.1007/s10551-010-0505-2

Ben-Amar, W., Chang, M., \& McIlkenny, P. (2017). Board gender diversity and corporate response to sustainability initiatives: Evidence from the carbon disclosure project. Journal of Business Ethics, 142(2), 369-383. https://doi.org/10.1007/s10551-015-2759-1

Bernardi, R. A., Bosco, S. M., \& Vassill, K. M. (2006). Does female representation on boards of directors associate with Fortune's "100 Best Companies to Work For" list? Business \& Society, 45(2), 235-248. https://doi.org/10.1177/0007650305283332

Botwinick, J. (1977). Aging and Behavior. New York: Springer. 
Boulouta, I. (2013). Hidden connections: The link between board gender diversity and corporate social performance. Journal of Business Ethics, 113(2), 185-197. https://doi.org/10.1007/s10551-012-1293-7

Brown, L. G. (1990). Convenience in services marketing. Journal of Services Marketing, 4(1), 53-59. https://doi.org/10.1108/EUM0000000002505

Burke, D. M., \& Light, L. L. (1981). Memory and aging: The role of retrieval processes. Psychological Bulletin, 90(3), 513. https://doi.org/10.1037/0033-2909.90.3.513

Campbell, D. (1987). Inkling-issues and observations. Issue and Observations, 7(2), 7-8.

Carlsson, G., \& Karlsson, K. (1970). Age, cohorts and the generation of generations. American Sociological Review, 710-718. https://doi.org/10.2307/2093946

Chen, C. J., \& Jaggi, B. (2000). Association between independent non-executive directors, family control and financial disclosures in Hong Kong. Journal of Accounting and Public Policy, 19(4-5), 285-310. https://doi.org/10.1016/S0278-4254(00)00015-6

Christy, J. A., Matolcsy, Z. P., Wright, A., \& Wyatt, A. (2010). The association between the market risk of equity and board characteristics. Working paper.

Ciocirlan, C., \& Pettersson, C. (2012). Does workforce diversity matter in the fight against climate change? An analysis of Fortune 500 companies. Corporate Social Responsibility and Environmental Management, 19(1), 47-62. https://doi.org/10.1002/csr.279

Cohen, A., \& Einav, L. (2007). Estimating risk preferences from deductible choice. American Economic Review, 97(3), 745-788. https://doi.org/10.1257/aer.97.3.745

Coles, J. L., Daniel, N. D., \& Naveen, L. (2008). Boards: Does one size fit all? Journal of Financial Economics, 87(2), 329-356. https://doi.org/10.1016/j.jfineco.2006.08.008

Cooper, E., \& Uzun, H. (2015). Corporate Social Responsibility and the Cost of Debt. Journal of Accounting and Finance, 15(8), 11-29.

Cucari, N., Esposito De Falco, S., \& Orlando, B. (2018). Diversity of board of directors and environmental social governance: Evidence from Italian listed companies. Corporate Social Responsibility and Environmental Management, 25(3), 250-266. https://doi.org/10.1002/csr.1452

Cullinan, C. P., Mahoney, L., \& Roush, P. B. (2019). Directors \& Corporate Social Responsibility: Joint Consideration of Director Gender and the Director's Role. Social and Environmental Accountability Journal, 39(2), 100-123. https://doi.org/10.1080/0969160X.2019.1586556

Datta, D. K., \& Rajagopalan, N. (1998). Industry structure and CEO characteristics: An empirical study of succession events. Strategic Management Journal, 19(9), 833-852. https://doi.org/10.1002/(SICI)1097-0266(199809)19:9<833::AID-SMJ971>3.0.CO;2-V

De Andres, P., Azofra, V., \& Lopez, F. (2005). Corporate boards in OECD countries: Size, composition, functioning and effectiveness. Corporate Governance: An International Review, 13(2), 197-210. https://doi.org/10.1111/j.1467-8683.2005.00418.x

Deschênes, S., Rojas, M., Boubacar, H., Prud'homme, B., \& Ouedraogo, A. (2015). The impact of board traits on the social performance of Canadian firms. Corporate Governance, 15(3), 293-305. https://doi.org/10.1108/CG-08-2014-0097

Dey, A. (2008). Corporate governance and agency conflicts. Journal of Accounting Research, 46(5), 1143-1181. https://doi.org/10.1111/j.1475-679X.2008.00301.x

Diamantopoulos, A., Schlegelmilch, B. B., Sinkovics, R. R., \& Bohlen, G. M. (2003). Can socio-demographics still play a role in profiling green consumers? A review of the evidence and an empirical investigation. Journal of Business Research, 56(6), 465-480. https://doi.org/10.1016/S0148-2963(01)00241-7

Eichholtz, P., Holtermans, R., Kok, N., \& Yönder, E. (2019). Environmental performance and the cost of debt: Evidence from commercial mortgages and REIT bonds. Journal of Banking \& Finance, 102, 19-32. https://doi.org/10.1016/j.jbankfin.2019.02.015

Esa, E., \& Ghazali, N. A. M. (2012). Corporate social responsibility and corporate governance in Malaysian government-linked companies. Corporate Governance (Bingley), 12(3), 292-305. https://doi.org/10.1108/14720701211234564

Fernandez-Feijoo, B., Romero, S., \& Ruiz, S. (2012). Does board gender composition affect corporate social 
responsibility reporting? International Journal of Business and Social Science, 3(1), 31-38.

Fernandez - Feijoo, B., Romero, S., \& Ruiz - Blanco, S. (2014). Women on boards: Do they affect sustainability reporting? Corporate Social Responsibility and Environmental Management, 21(6), 351-364. https://doi.org/10.1002/csr.1329

Ferrero - Ferrero, I., Fernández - Izquierdo, M. Á., \& Muñoz - Torres, M. J. (2015). Integrating sustainability into corporate governance: An empirical study on board diversity. Corporate Social Responsibility and Environmental Management, 22(4), 193-207. https://doi.org/10.1002/csr.1333

Galbreath, J. (2013). ESG in focus: The Australian evidence. Journal of Business Ethics, 118(3), 529-541. https://doi.org/10.1007/s10551-012-1607-9

Gallego - Álvarez, I., \& Pucheta - Martínez, M. C. (2020). Environmental strategy in the global banking industry within the varieties of capitalism approach: The moderating role of gender diversity and board members with specific skills. Business Strategy and the Environment, 29(2), 347-360. https://doi.org/10.1002/bse.2368

Giannarakis, G. (2014). The determinants influencing the extent of CSR disclosure. International Journal of Law and Management, 56(5), 393-416. https://doi.org/10.1108/IJLMA-05-2013-0021

Gibson, C. B. (2004). Building multicultural teams: Learning to manage homogeneity and heterogeneity. In N. A. Boyacigiller, R. A. Goodman \& M. E. Phillips (Eds.), Crossing Cultures: Insights from Master Teachers. Malden, MA: Blackwell. Retrieved from http://web.gsm.uci.edu/ cgibson/Publication\%20files/Articles/Crossing\%20cultures\%20chapter.pdf

Glass, C., Cook, A., \& Ingersoll, A. R. (2016). Do women leaders promote sustainability? Analyzing the effect of corporate governance composition on environmental performance. Business Strategy and the Environment, 25(7), 495-511. https://doi.org/10.1002/bse.1879

Guest, P. M. (2009). The impact of board size on firm performance: Evidence from the UK. The European Journal of Finance, 15(4), 385-404. https://doi.org/10.1080/13518470802466121

Guthrie, J. P., \& Olian, J. D. (1991). Does context affect staffing decisions? The case of general managers. Personnel Psychology, 44(2), 263-292. https://doi.org/10.1111/j.1744-6570.1991.tb00959.x

Hafsi, T., \& Turgut, G. (2013). Boardroom diversity and its effect on social performance: Conceptualization and empirical evidence. Journal of Business Ethics, 112(3), 463-479. https://doi.org/10.1007/s10551-012-1272-z

Halek, M., \& Eisenhauer, J. G. (2001). Demography of risk aversion. Journal of Risk and Insurance, 1-24. https://doi.org/10.2307/2678130

Hambrick, D. C., Cho, T. S., \& Chen, M. J. (1996). The Influence of Top Management Team Heterogeneity on Firms' Competitive Moves. Administrative Science Quarterly, 41(4). https://doi.org/10.2307/2393871

Hambrick, D. C., \& Mason, P. A. (1984). Upper echelons: The organization as a reflection of its top managers. Academy of Management Review, 9(2), 193-206. https://doi.org/10.5465/amr.1984.4277628

Handajani, L., Subroto, B., Sutrisno, T., \& Saraswati, E. (2014). Does board diversity matter on corporate social disclosure? An Indonesian evidence. Journal of Economics and Sustainable Development, 5(9), 8-16.

Haniffa, R. M., \& Cooke, T. E. (2005). The impact of culture and governance on corporate social reporting. Journal of Accounting and Public Policy, 24(5), 391-430. https://doi.org/10.1016/j.jaccpubpol.2005.06.001

Harjoto, M. A., Laksmana, I., \& Wen, Y. Y. (2019). Board nationality and educational background diversity and corporate social performance. Corporate Governance: The International Journal of Business in Society, 19(2), 217-239. https://doi.org/10.1108/CG-04-2018-0138

Harrison, R., Papp, B., Pál, C., Oliver, S. G., \& Delneri, D. (2007). Plasticity of genetic interactions in metabolic networks of yeast. Proceedings of the National Academy of Sciences, 104(7), 2307-2312. https://doi.org/10.1073/pnas.0607153104

Hollindale, J., Kent, P., Routledge, J., \& Chapple, L. (2019). Women on boards and greenhouse gas emission disclosures. Accounting \& Finance, 59(1), 277-308. https://doi.org/10.1111/acfi.12258

Holtz, L., \& SarloNeto, A. (2014). Effects of board of directors' characteristics on the quality of accounting information in Brazil. Revista Contabilidade \& Finanças, 25(66), 255-266. https://doi.org/10.1590/1808-057x201412010 
Hussain, N., Rigoni, U., \& Orij, R. P. (2018). Corporate Governance and Sustainability Performance: Analysis of Triple Bottom Line Performance. Journal of Business Ethics, 149(2), 411-432. https://doi.org/10.1007/s10551-016-3099-5

Ibrahim, A. H., \& Hanefah, M. M. (2016). Board diversity and corporate social responsibility in Jordan. Journal of Financial Reporting and Accounting, 14(2), 279-298. https://doi.org/10.1108/JFRA-06-2015-0065

Ibrahim, N. A., \& Angelidis, J. P. (1995). The corporate social responsiveness orientation of board members: Are there differences between inside and outside directors? Journal of Business Ethics, 14(5), 405-410. https://doi.org/10.1007/BF00872102

Ibrahim, N. A., Howard, D. P., \& Angelidis, J. P. (2003). Board members in the service industry: An empirical examination of the relationship between corporate social responsibility orientation and directorial type. Journal of Business Ethics, 47(4), 393-401. https://doi.org/10.1023/A:1027334524775

Janggu, T., Darus, F., Zain, M. M., \& Sawani, Y. (2014). Does good corporate governance lead to better sustainability reporting? An analysis using structural equation modeling. Procedia-Social and Behavioral Sciences, 145, 138-145. https://doi.org/10.1016/j.sbspro.2014.06.020

Jizi, M. I., Salama, A., Dixon, R., \& Stratling, R. (2014). Corporate governance and corporate social responsibility disclosure: Evidence from the US banking sector. Journal of Business Ethics, 125(4), 601-615. https://doi.org/10.1007/s10551-013-1929-2

Jo, H., \& Harjoto, M. A. (2011). Corporate governance and firm value: The impact of corporate social responsibility. Journal of Business Ethics, 103(3), 351-383. https://doi.org/10.1007/s10551-011-0869-y

Kaymak, T., \& Bektas, E. (2017). Corporate social responsibility and governance: Information disclosure in multinational corporations. Corporate Social Responsibility and Environmental Management, 24(6), 555-569. https://doi.org/10.1002/csr.1428

Khan, H. U. Z. (2010). The effect of corporate governance elements on corporate social responsibility (CSR) reporting: Empirical evidence from private commercial banks of Bangladesh. International Journal of Law and Management, 52(2), 82-109. https://doi.org/10.1108/17542431011029406

Kiliç, M., Kuzey, C., \& Uyar, A. (2015). The impact of ownership and board structure on Corporate Social Responsibility (CSR) reporting in the Turkish banking industry. Corporate Governance, 15(3), 357-374. https://doi.org/10.1108/CG-02-2014-0022

Kocher, M. G., \& Sutter, M. (2005). The decision maker matters: Individual versus group behaviour in experimental beauty - contest games. The Economic Journal, 115(500), 200-223. https://doi.org/10.1111/j.1468-0297.2004.00966.x

Konrad, A. M., Kramer, V., \& Erkut, S. (2008). The impact of three or more women on corporate boards. Organizational Dynamics, 37(2), 145-164. https://doi.org/10.1016/j.orgdyn.2008.02.005

Krishnan, G., \& Visvanathan, G. (2009). Do auditors price audit committee's expertise? The case of accounting versus nonaccounting financial experts. Journal of Accounting, Auditing \& Finance, 24(1), 115-144. https://doi.org/10.1177/0148558X0902400107

Laksmana, I. (2008). Corporate board governance and voluntary disclosure of executive compensation practices. Contemporary Accounting Research, 25(4), 1147-1182. https://doi.org/10.1506/car.25.4.8

Lim, S., Matolcsy, Z., \& Chow, D. (2007). The association between board composition and different types of voluntary disclosure. European Accounting Review, 16(3), 555-583. https://doi.org/10.1080/09638180701507155

Litov, L. P., Sepe, S. M., \& Whitehead, C. (2014). Lawyers and Fools: Lawyer-Directors in Public Corporations. Georgetown Law Journal, 102(2), 413-480. https://doi.org/10.2139/ssrn.2218855

Mallin, C., Michelon, G., \& Raggi, D. (2013). Monitoring intensity and stakeholders' orientation: How does governance affect social and environmental disclosure? Journal of Business Ethics, 114(1), 29-43. https://doi.org/10.1007/s10551-012-1324-4

Manita, R., Bruna, M. G., Dang, R., \& Houanti, L. H. (2018). Board gender diversity and ESG disclosure: Evidence from the USA. Journal of Applied Accounting Research, 19(2), 206-224. https://doi.org/10.1108/JAAR-01-2017-0024

Matuszak, Ł., Różańska, E., \& Macuda, M. (2019). The impact of corporate governance characteristics on banks' 
corporate social responsibility disclosure: Evidence from Poland. Journal of Accounting in Emerging Economies, 9(1). https://doi.org/10.1108/JAEE-04-2017-0040

Morin, R. A., \& Suarez, A. F. (1983). Risk aversion revisited. The Journal of Finance, 38(4), 1201-1216. https://doi.org/10.1111/j.1540-6261.1983.tb02291.x

Naciti, V. (2019). Corporate governance and board of directors: The effect of a board composition on firm sustainability performance. Journal of Cleaner Production, 237, 117727. https://doi.org/10.1016/j.jclepro.2019.117727

Nurhayati, R., Taylor, G., \& Tower, G. (2015). Investigating social and environmental disclosure practices by listed Indian textile firms. The Journal of Developing Areas, 49(6), 361-372. https://doi.org/10.1353/jda.2015.0109

Oikonomou, I., Brooks, C., \& Pavelin, S. (2014). The Effects of Corporate Social Performance on the Cost of Corporate Debt and Credit Ratings. Financial Review, 49(1), 49-75. https://doi.org/10.1111/fire.12025

Ong, T., \& Djajadikerta, H. G. (2018). Corporate governance and sustainability reporting in the Australian resources industry: An empirical analysis. Social Responsibility Journal, 16(1), 1-14 https://doi.org/10.1108/SRJ-06-2018-0135

Pålsson, A. M. (1996). Does the degree of relative risk aversion vary with household characteristics? Journal of Economic Psychology, 17(6), 771-787. https://doi.org/10.1016/S0167-4870(96)00039-6

Pathan, S. (2009). Strong boards, CEO power and bank risk-taking. Journal of Banking \& Finance, 33(7), 1340-1350. https://doi.org/10.1016/j.jbankfin.2009.02.001

Post, C., Rahman, N., \& Rubow, E. (2011). Green governance: Boards of directors' composition and environmental corporate social responsibility. Business \& Society, 50(1), 189-223. https://doi.org/10.1177/0007650310394642

Prado-Lorenzo, J. M., \& Garcia-Sanchez, I. M. (2010). The role of the board of directors in disseminating relevant information on greenhouse gases. Journal of Business Ethics, 97(3), 391-424. https://doi.org/10.1007/s10551-010-0515-0

Rao, K., \& Tilt, C. (2016). Board composition and corporate social responsibility: The role of diversity, gender, strategy and decision making. Journal of Business Ethics, 138(2), 327-347. https://doi.org/10.1007/s10551-015-2613-5

Riley Jr, W. B., \& Chow, K. V. (1992). Asset allocation and individual risk aversion. Financial Analysts Journal, 48(6), 32-37. https://doi.org/10.2469/faj.v48.n6.32

Setó - Pamies, D. (2015). The relationship between women directors and corporate social responsibility. Corporate Social Responsibility and Environmental Management, 22(6), 334-345. https://doi.org/10.1002/csr.1349

Souren, P., Priya, S., Imad, S., \& Mykytyn, P. (2004). Impact of heterogeneity and collaborative conflict management style on the performance of synchronous global virtual teams. Information and Management, 4l(3), 303-321. https://doi.org/10.1016/S0378-7206(03)00076-4

Vroom, V. H., \& Pahl, B. (1971). Relationship between age and risk taking among managers. Journal of Applied Psychology, 55(5), 399. https://doi.org/10.1037/h0031776

Wailerdsak, N., \& Suehiro, A. (2004). Top executive origins: Comparative study between Japan and Thailand. Asian Business \& Management, 3(1), 85-104. https://doi.org/10.1057/palgrave.abm.9200071

Walls, J. L., \& Berrone, P. (2017). The power of one to make a difference: How informal and formal CEO power affect environmental sustainability. Journal of Business Ethics, 145(2), 293-308. https://doi.org/10.1007/s10551-015-2902-z

Walls, J. L., Berrone, P., \& Phan, P. H. (2012). Corporate governance and environmental performance: Is there really a link? Strategic Management Journal, 33(8), 885-913. https://doi.org/10.1002/smj.1952

Walls, J. L., \& Hoffman, A. J. (2013). Exceptional boards: Environmental experience and positive deviance from institutional norms. Journal of Organizational Behavior, 34(2), 253-271. https://doi.org/10.1002/job.1813

Wang, J., \& Coffey, B. S. (1992). Board composition and corporate philanthropy. Journal of Business Ethics, 11(10), 771-778. https://doi.org/10.1007/BF00872309

Webb, E. (2004). An examination of socially responsible firms' board structure. Journal of Management and 
Governance, 8(3), 255-277. https://doi.org/10.1007/s10997-004-1107-0

Williams, R. J. (2003). Women on corporate boards of directors and their influence on corporate philanthropy. Journal of Business Ethics, 42(1), 1-10. https://doi.org/10.1023/A:1021626024014

Zhang, D., Lowry, P. B., Zhou, L., \& Fu, X. (2007). The impact of individualism—collectivism, social presence, and group diversity on group decision making under majority influence. Journal of Management Information Systems, 23(4), 53-80. https://doi.org/10.2753/MIS0742-1222230404

\section{Copyrights}

Copyright for this article is retained by the author, with first publication rights granted to the journal.

This is an open-access article distributed under the terms and conditions of the Creative Commons Attribution license (http://creativecommons.org/licenses/by/4.0/). 